\title{
John Russell-Wood: obituário de um membro do Conselho da RBPI
}

PAULO ROBERTO DE ALMEIDA*

A historiografia brasileira moderna muito deve aos historiadores ingleses, a começar pelo "patrão" da tribo, Robert Southey, com sua History of Brazil (em três volumes: 1810-19), a primeira escrita em inglês. Seguiram-se muitos outros nos séculos 19 e 20, entre os quais Charles Boxer, o grande especialista no mundo colonial português e seu império marítimo, com suas ramificaçōes nas Américas, na África e na Ásia (onde ele, aliás, tinha servido como militar).

O historiador John Russell-Wood, nascido galês, educado na Inglaterra e radicado desde longos anos nos Estados Unidos, seguiu essa mesma tradição de estudos historiográficos centrados no mundo colonial português, sem no entanto ter passado pelas forças armadas de sua majestade britânica. Graduou-se em história moderna pela Universidade de Oxford (1961), onde também fez seu mestrado (1963) e doutorado (1967), e estudou na Universidade de Coimbra, onde consolidou definitivamente sua reputação de historiador do universo português. Ao falecer, aos 70 anos, no dia 13 de agosto de 2010, ele lecionava desde 1971 no departamento de História da Universidade Johns Hopkins, em Baltimore, onde se ocupava da América Latina colonial, com ênfase no mundo português. Foi justamente Charles Boxer, nos seus tempos de Oxford, quem o inspirou a se dedicar ao papel do Brasil no império colonial português.

Seus estudos nessa área foram muito ecléticos, incluindo pesquisas em história administrativa, das instituições, da arte, da tecnologia, da medicina, da família, das mulheres, sobre as raças e a escravidão. Um de seus mais destacados livros se ocupava, justamente, de Slavery and Freedom in Colonial Brazil: (1982, 1993 e 2002), no qual ele mostrava que as relações raciais no Brasil colonial estavam mais para o chiaroscuro (que é o título de um dos capítulos) do que para o black-and-white da experiência dos Estados Unidos. Ele tinha vivido no Brasil, concentrado em suas pesquisas sobre o período colonial, entre 1964 e 1970, quando percorreu muitos arquivos e leu inúmeros relatórios sobre as irmandades e as casas de misericórdia (sobre a Santa Casa da Bahia publicou Fidalgos and Philantropists, em 1968). Entre seus outros livros, consolidando seu vasto conhecimento sobre o Brasil colonial e o império português podem ser

* PhD em Ciências Sociais e Diplomata de carreira (pralmeida@me.com). 
citados: Society and government in colonial Brazil, 1500-1822 (1992) e Portuguese empire, 1415-1808: a world on the move (1998).

Não contente em orientar seus muitos alunos em estudos brasileiros, ele os recebia em sua casa de Lutherville e mantinha relaçôes pessoais com todos eles, organizando festas nos grandes feriados americanos. Eu o conheci pessoalmente nos encontros de brasilianistas que ajudei a organizar quando de minha estada na Embaixada em Washington (quando também sugeri o seu nome para a ordem de Rio Branco) e ele surpreendeu-me imediatamente pelo seu bom-humor e disposição em colaborar em nossos empreendimentos acadêmicos.

Recebido em 30 de agosto de 2010 Aprovado em 18 de novembro de 2010 